\title{
GNAQ Gene Mutation
}

National Cancer Institute

\section{Source}

National Cancer Institute. GNAQ Gene Mutation. NCI Thesaurus. Code C89713.

A somatic mutation of the GNAQ gene which encodes guanine nucleotide-binding protein $\mathrm{G}(\mathrm{q})$ subunit alpha. 